\title{
PENGARUH ARUS KAS TERHADAP HARGA SAHAM PADA PERUSAHAAN MANUFAKTUR SUB SEKTOR MAKANAN DAN MINUMAN YANG TERDATAR DI BEI
}

\author{
${ }^{1}$ Amanda agustia Pasaribu, ${ }^{2}$ Nilawati Nasti, ${ }^{3}$ Mas'ut, ${ }^{4}$ Shofwan Andri \\ ${ }^{1,2,3,4}$ Universitas Islam Sumatera Utara \\ Iamandaagustya1808@gmail.com, 22hj.nilawatinasti@yahoo.co.id, ${ }^{3}$ m.masut@yahoo.com, \\ ${ }^{4}$ shofwan.andri@fe.uisu.ac.id
}

\begin{abstract}
This study aims to the effect of cash flow on stock prices in food beverage sub-sectorMaufacturing Companies listed on the Indonesia Stock Exchange. This study has a population of 21 companies that are Food and Beverage Sub Sector Manufacturing Companies listed on the Indonesia Stock Exchange during 2018-2020 which are then determined to be sampled using a purposive sampling method to obtain a sample of 13 Food and Beverage Sub Sector Manufacturing Companies by Specified criteria. The analytical method used is quantitative descriptive. Data analysis includes data feasibility test, regression analysis, and hypothesis testing partially and simultaneously. The result of this study indicate that (1) Operating Cash Flow has no effect on stock prices, (2) Investment Cash Flow has no effect on stock prices, (3) Funding cash flow has a significant effect on stock prices, (4) the effect operating cash flow, investment cash flow, and funding cash flow has no effect on stock prices.
\end{abstract}

Keywords: Cash Flow, Stock Prices, Food and Beverage Sub Sector.

ABSTRAK : Penelitian ini bertujuan untuk mengetahui pengaruh arus kas terhadap harga saham pada perusahaan Manufaktur Sub Sektor makanan dan minuman yang terdaftar di Bursa Efek Indonesia. Penelitian ini memiliki populasi 21 perusahaan yang merupakan perusahaan manufaktur Sub Sektor Makanan dan Minuman yang terdaftar di Bursa Efek Indonesia selama tahun 2018-2020 yang kemudian ditentukan menjadi sampel dengan menggunakan Purposive Sampling sehingga memperoleh sampel sebanyak 13 Perusahaan Manufaktur Sub Sektor Makanan dan Minuman yang sesuai dengan Kriteria yang ditentukan. Metode Analisis yang digunakan adalah Deskriptif Kuantitatif. Analisis data meliputi uji kelayakan data, analisis regresi, serta pengujian hipotesis secara pasrsial dan simultan. Hasil penelitian ini menunjukkan bahwa (1) Pengaruh arus kas operasi terhadap harga saham Negatif, (2) pengaruh arus kas investasi terhadap harga saham negatif, (3) pengaruh arus kas pendanaan terhadap harga saham positif dan signifikan, (4) pengaruh arus kas operasi, investasi, dan pendanaan tidak bepengaruh terhadap harga saham.

Kata Kunci : Arus Kas, Harga Saham, Sub Sektor Makanan dan Minuman.

\section{Pendahuluan}

\subsection{Latar Belakang}

Dari berbagai fungsi yang ada, kegunaan terbit pasaran kapital yaitu sebagai wadah penghimpun dana yang bersumber dari publik ke berbagai sektor yang memimpin pendanaan serta yang didapat melalui pembiayaan dari dalam perusahaan (internal financing) ataupun pembiayaan berusul bagian luar perusahaan (external financing). (Setyawan et al., 2020)". Dari kontribusitercantum menjadi elemen pembelian bahan baku, tenaga kerja, prasarana fisik dan teknologi serta keahlian manajamen. Era menuju Republik Indonesia (RI) 4.0. semua perusahaan yang berdiri di tuntut untuk mendapatkan laba yang maksimal. Laba yang didapatkan perusahaan merupakan salah satu hal utama untuk menunjang keberhasilan suatu perusahaan.

Hal konvensional yang diperlukan oleh para investor untuk bersedia menyalurkan dananya melalui pasaran aktiva adalah investor memerlukan jika ketika mereka berinvestasi modal yang diinvestasikan aman. Dikatakan aman apabila para investor mendapat informasi yang jelas, detail, tepat waktu. Dengan adanya informasi yang jelas serta detail, maka calon investor akan mempertimbangkan untuk 
mereka melakukanpenanaman modal di suatu perusahaan, dengan adanyainformasi dari laporan keuangan yang terperinci akan membangun kepercayaan dari kalangan investor.

Perusahaan yang bergiat di tempat industri makanan dan minuman merupakan perusahaan yang sangat berlaku penting bagi seluruh masyarakat dari belahan dunia termasuk masyarakat Indonesia, karena makanan dan minuman merupakan kebutuhan pokok yang tidak absolusi berasal kebutuhan sehari-hari. oleh karena itu makanan dan minuman sangat berperan penting bagi setiap makhluk hidup. Perusahaan yang bergerak dibidang makanan dan minuman menjadi daya tarik bagi investor untuk bergabung di antara perusahaan lainnya, sub sektor ini menarik para investor untuk menanamkan sahamnya karena bisa dinilai mempunyai prospek yang menguntungkan dibandingkan dengan sektor lainnya dan juga mendapatkan laba bagian dalam jangka panjang.

\section{Landasan Teori}

\subsection{Laporan Keuangan}

Menurut Standar Akuntansi Keuangan (SAK) mendefenisikan bahwa "laporan keuangan ini ialah suatu bagian dari suatu proses pelaporan keuangan yang lengkap, melingkupi, neraca, laporan laba rugi, laporan perubahan posisi keuangan (yakni arus kas, atau juga arus dana, catatan, serta juga laporan lain) serta juga materi penjelasan yang merupakan baigian integral darinya." (Keuangan, 2015)

\subsection{Laporan Arus Kas}

Laporan arus kas merupakansejenis informasi yang menyerahkan data laporan kas di perusahaan yang tergantung dengan penerimaan dan pengeluaran kas yang dapat diklasifikasikan bedasarkan 3 aktivitas yaitu aktivitas operasi, investasi, dan pendanaan dalam periode tertentu.

\subsection{Arus Kas Operasional}

Arus kas Aktivitas Operasi (cash flow operating activities) merupakan pengeluaran dan pemasukan kas bersumber komersial inti aktivitas ini seperti penghasil utama pendapatan entitas dan aktivitas lain yang bukan merupakan aktivitas investasi dan aktivitas pendanaan.

\subsection{Arus Kas Investasi}

Menurut (Laoh, 2014) Arus kas investasi adalah aktivitas yang menyangkut perolehan atau pelepasan aktiva jangka panjang (aktivita tidak lancar) serta investasi lain yang tidak termasuk dalam setara kas, mencakup aktivitas meminjamkan uang dan mengumpulkan piutang tersebut. Serta memperoleh dan menjual investasi dan aktivita jangka panjang produktif. (Suhairi, 2006).

\subsection{Arus Kas Pendanaan}

Menurut (Maryati, 2020) mengungkapkan bahwa aktivitas pendanaan melaporkan transaksi kas yang berhubungan dengan investasi kas oleh pemilik, peminjaman dan penarikan oleh pemilik.

\subsection{Saham}

Menurut (Okt, 2011) saham adalah surat berharga yang merupakan tanda kepemilikan seseorang atau badan terhadap suatu perusahaan. Surat berharga yang dikeluarkan oleh sebuah perusahaan yang berbentuk Perseroan Terbatas (PT) atau yang biasa disebut emiten. Jenis saham berdasarkan dari segi hak tagih atau klaim yaitu sebagai berikut:

a. Saham biasa (Common Stock)

b. Saham preferen (Preferred Stock)

c. Dilihat dari cara pemeliharaanya, saham dibedakan menjadi:

1. Saham atas unjuk (Bearer Stock

2. Saham atas nama (Registered Stock)

d. Ditinjau dari kinerja perdagangan, maka saham dikategorikan menjadi:

1. Saham unggulan (Blue-chip Stock)

2. Saham pendapatan (Income Stock)

3. Saham pertumbuhan (Growth Stock-well Known)

4. Saham Spekulatif (Spekulative Stock)

5. Saham Siklikal (Counter Cyclical Stock)(N. Rahmawati, 2019)".

\subsection{Harga Saham}

Harga saham merupakan salah satu indikator pengelolaan perusahaan. Keberhasilan untuk menghasilkan keuntungan dapat memberikan kepuasan bagi investor yang memiliki rasional, dengan harga saham tinggi bisa memberikan keuntungan yang baik sehingga memudahkan pihak manajemen untuk mendapatkan dana dari luar.(N. Rahmawati, 2019)

Beberapa jenis harga saham menurut widioatmojo, sebagai berikut:

1) Harga Nominal

2) Harga Perdana 
3) Harga Pasar

4) Harga Pembukuan

5) Harga Penutupan

6) Harga Tertinggi

7) Harga Terendah

8) Harga Rata-rata.(Pahlevi, 2019)".

\section{Metode Penelitian}

\subsection{Populasi Peneltian}

Populasi (Population) adalah keseluruhan informasi yang menjadi pusat perhatian seorang peneliti dalam ruang lingkup dan waktu yang telah ditentukan. Pupulasi berkaitan dengan data-data, kemudian populasi merupakan keseluruhan jumlah yang terdiri atas objek atau subjek yang mempunyai karakteristik dan kualitas tertentu yang ditetapkan oleh peneliti untuk diteliti kemudian ditarik kesimpulannya. Anggota populasi disebut dengan elemen populasi (Population Element).

Populasi yang akan digunakan dalam penelitian ini adalah perusahaan manufaktur sub sektor makanan dan minuman yang terdaftar di Bursa Efek Indonesia selama periode tahun 2018-2020 sebanyak 63 laporan keuangan.

Tabel 1. Daftar Populasi Penelitian

\begin{tabular}{|c|l|c|}
\hline No. & \multicolumn{1}{|c|}{ Nama Perusahaan } & Kode \\
\hline 1 & Tri Bayan Tirta Tbk. & ALTO \\
\hline 2 & Akasha Wira International Tbk. & ADES \\
\hline 3 & Tiga Pilar Sejahtera Food Tbk. & AISA \\
\hline 4 & Bumi Teknokultura Unggul Tbk. & BTEK \\
\hline 5 & Budi Starch \& Sweetener Tbk. & BUDI \\
\hline 6 & Campina Ice Cream Industry Tbk & CAMP \\
\hline 7 & Wilmar Cahaya Indonesia Tbk. & CEKA \\
\hline 8 & Sariguna Primatirta Tbk. & CLEO \\
\hline 9 & Wahana Interfood Nusantara Tbk. & COCO \\
\hline 10 & Delta Djakarta Tbk. & DLTA \\
\hline 11 & Diamond Food Indonesia Tbk. & DMND \\
\hline 12 & Sentra Food Indonesia Tbk. & FOOD \\
\hline 13 & Garudafood Putra Putri Jaya Tbk. & GOOD \\
\hline 14 & Buyung Poetra Sembada Tbk. & HOKI \\
\hline 15 & Indofood CBP Sukses Makmur Tbk. & ICBP \\
\hline 16 & Era Mandiri Cemerlang Tbk. & IKAN \\
\hline 17 & Magna Investama Mandiri Tbk. & MGNA \\
\hline 18 & Pratama Abadi Nusa Industri Tbk. & PANI \\
\hline 19 & Prima Cakrawala Abadi Tbk. & PCAR \\
\hline 20 & Nippon Indosari Corpindo Tbk. & ROTI \\
\hline 21 & Ultra Jaya Milk Industry Tbk. & ULTJ \\
\hline
\end{tabular}

Sumber : Bursa Efek Indonesia

\subsection{Sampel}

Sampel merupakan satu sisi dari perhitungan dan karakteristik yang dimiliki oleh populasi, ataupun bagian kecil dari anggota populasi yang diambil menurut prosedur tertentu sehingga dapat mewakili populasi tersebut. Jika populasi besar, dan yang ada di populasi, missal karena keterkaitan dana, energi dan waktu.Maka penelitian ini dapat menggunakan sampel yang di ambil dari populasi tersebut. Sampel penelitian adalah 13 perusahaan dikali 3 tahun jadi sebanyak 39 laporan keuangan”. peneliti tidak mungkin mempelajari seluruh

\section{Hasil Penelitian}

Tabel 2. HasilAnalisis Deskriptif Statistik

DescriptiveStatistics

\begin{tabular}{ll|l|l|l|l}
$\mathrm{N}$ & \multicolumn{2}{|c|}{ Minimum } & \multicolumn{1}{|c}{ Maximum } & \multicolumn{1}{c}{ Mean } & \multicolumn{1}{c}{ Std. Deviation } \\
\hline ArusKas & 39 & $12.183,00$ & 1.088 .089 .209 .3 & 118.086 .339 .742 & $227.163 .437 .275,48$ \\
Operasi & & & 81,00 &, 2052 & 877
\end{tabular}




\begin{tabular}{ll|l|l|l|l}
\multicolumn{1}{c}{$\mathrm{N}$} & & Minimum & \multicolumn{1}{|c}{ Maximum } & \multicolumn{1}{c}{ Mean } & \multicolumn{1}{c}{ Std. Deviation } \\
\hline $\begin{array}{l}\text { ArusKas } \\
\text { Investasi }\end{array}$ & 39 & $2.536,00$ & $\begin{array}{l}1.289 .520 .404 .2 \\
49,00\end{array}$ & $\begin{array}{l}154.829 .683 .599 \\
2564\end{array}$ & $\begin{array}{l}287.733 .824 .157,64 \\
830\end{array}$ \\
\hline $\begin{array}{l}\text { ArusKasPenda } \\
\text { naan }\end{array}$ & 39 & 726,00 & $\begin{array}{l}543.604 .133 .261 \\
00\end{array}$ & 73.385 .564 .419$, & $\begin{array}{l}119.647 .006 .655,67 \\
651\end{array}$ \\
\hline HargaSaham & 39 & 50,00 & $7.925,00$ & $1.675,6923$ & $2.295,74892$ \\
\hline $\begin{array}{l}\text { ValidN } \\
\text { (listwise) }\end{array}$ & 39 & & & & \\
\hline
\end{tabular}

Sumber:DataDiolah denganSPSS (2021)

\section{Arus Kas Operasi}

Dari seluruh perusahaan manufaktur sub sektor makanan dan minuman periode20182020 memiliki nilai minimum sebesar Rp12.183,00 dengan nilai maksimum sebesar Rp1.088.089.209.381,00danrataratasebesarRp118.086.339.742,20serta standardeviasisebesarRp227.163.437.275,48".

\section{Arus Kas Investasi}

Arus kas investasi memiliki nilai minimum sebesar Rp2.536,00 dengan nilai maksimum sebesar Rp1.289.520.404.249,00danrataratasebesarRp154.829.683.599,25sertastandar deviasisebesarRp287.733.824.157,64”.

\section{Arus Kas Pendanaan}

"Arus kas pendanaan memiliki nilai minimum sebesar Rp726,00 dengan nilai maksimum sebesar Rp543.604.133.261,00 dan rata-ratasebesar Rp73.385.564.419,79 serta standar deviasisebesarRp119.647.006.655,67”.

\section{Harga Saham}

Harga saham memiliki nilai minimum sebesar Rp50,00 dengan nilai maksimum sebesar Rp7.925,00 dan rata-rata sebesar Rp1.675,69 serta deviasi sebesar Rp2.295,74”.

\subsection{Uji Asumsi Klasik \\ 4.4.1. Uji Normalitas}

Uji normalitas dalam penelitian ini dilakukan dengan pendekatan statistik dan grafik, yaitu Kolmogorov Smirnov, Histogram, dan P-PPlot.

Tabel 3. HasilUjiNormalitas dengan Komogorov Smirnov One-SampleKolmogorov-SmirnovTest

\begin{tabular}{|c|c|c|}
\hline \multicolumn{2}{|l|}{$\mathrm{N}$} & 39 \\
\hline \multirow{2}{*}{ Normal Parameters ${ }^{a}$} & Mean &, 000000 \\
\hline & Std.Deviation & 1,2898732 \\
\hline \multirow[t]{3}{*}{ Most ExtremeDifferences } & Absolute &, 078 \\
\hline & Positive & ,078 \\
\hline & Negative &,- 048 \\
\hline Test Statistic & &, 078 \\
\hline Asymp. Sig. (2-tailed) & & 200 \\
\hline
\end{tabular}

Dapat dilihat bahwa nilai Asymp.Sig.(2tailed) sebesar 0,20>0,05 yang artinya melalui Komogorov Smirnov data yang digunakan dalam penelitian ini telah berdistribusi normal dan layak digunakan. 


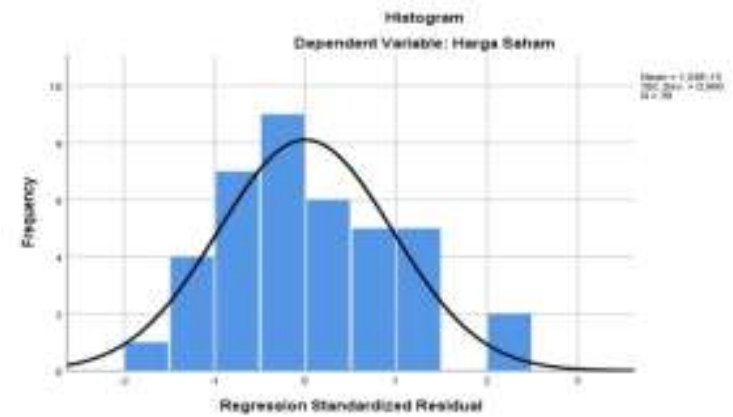

Gambar 1. Hasil Uji Normalitas dengan Histogram

Dapat dilihat bahwa bentuk histogram menguikuti bentuk garis diagonal yang artinya berdasarkan uji normalitas dengan histogram data yang digunakan dalam penelitian ini telah berdistribusi normal danlayak digunakan. Kemudianu ntuk hasil uji normalitas menggunakan P-P Plot dapat dilihat pada Gambar dibawah.

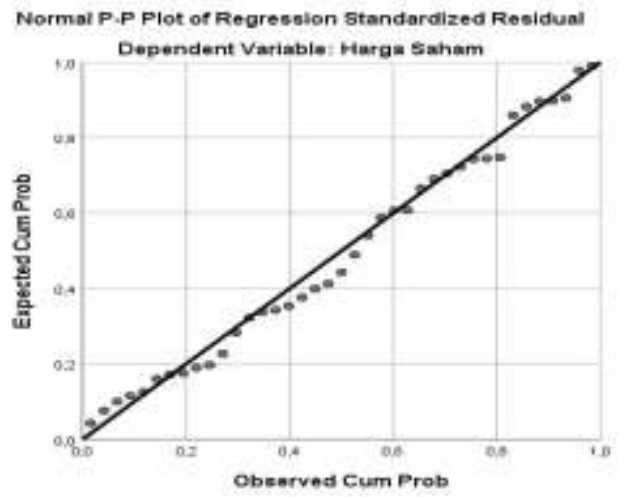

Gambar 2. HasilUjiNormalitasdengan P-P Plot

Dapat dilihat bahwa bentuk plot menguikuti bentuk garis diagonal yang artinya berdasarkan uji normalitas dengan P-PPlot data yang digunakan dalam penelitian ini telah berdistribusi normal dan layak digunakan".

\subsubsection{Hasil uji multikolinearitas}

Tabel 4. HasilUjiMultikolinearitas

\section{Coefficients $^{\text {a }}$}

\section{Standardized}

Coefficients

Beta
UnstandardizedCoefficients

Collinearity Statistics

\begin{tabular}{lr|r|r|r|r} 
Model & \multicolumn{1}{c|}{ B } & Std.Error & Beta & Tolerance & VIF \\
\hline 1 (Constant) & 5,656 &, 921 & & & \\
\hline Arus Kas Operasi &,- 094 &, 147 &,- 384 &, 067 & 1,824 \\
\hline Arus Kas Investasi &,- 178 &, 120 &,- 860 &, 072 & 1,812 \\
\hline Arus Kas Pendanaan &, 317 &, 144 & 1,412 &, 059 & 1,811 \\
\hline
\end{tabular}

a. Dependent Variable:Harga Saham

Sumber:DataDiolahdengan SPSS (2021)

Melalui tabel 4, dapat dilihat bahwa variabel arus kas operasi memiliki nilai tolerance sebesar 0,67>0,1 dengan nilai VIF sebesar $1,824<10$. Variabel arus kas investasi memiliki nilai tolerance sebesar $0,72>0,1$ dengan nilai VIF sebesar $1,812<10$. Variabel arus kas pendanaan memiliki nilai tolerance sebesar0,59 $>0,1$ dengan nilai VIF sebesar1,811 < 10 . Hal tersebut menunjukkan bahwa tidak terdapat gejala multikolinearitas pada data yang digunakan dalam penelitian ini dan data layak digunakan sebagai model regresi”.

\subsubsection{Hasil uji autokorelasi}

\begin{tabular}{|c|c|c|c|c|c|}
\hline \multicolumn{6}{|c|}{ Model Summary ${ }^{b}$} \\
\hline Model & $\mathrm{R}$ & R Square & $\begin{array}{c}\text { Adjusted } \\
\text { Square }\end{array}$ & $\begin{array}{l}\mathrm{R} \text { Std.Error ofthe } \\
\text { Estimate }\end{array}$ & Durbin-Watson \\
\hline 1 & $383^{a}$ & ,147 & ,173 & 1,34402 &, 595 \\
\hline
\end{tabular}


Melalui Tabel dapat dilihat bahwa nilai DW sebesar $0,595<1,725$ yang artinya menunjukkan bahwa tidak terdapat gejala autokorelasi pada data yang digunakan dalam penelitian ini dan data layak digunakan sebagai model regresi”.

\subsection{HasilRegresiLinear Berganda}

Tabel 6. Hasil RegresiLinearBerganda

\begin{tabular}{|c|c|c|c|c|c|c|c|}
\hline \multirow[b]{2}{*}{ Model } & $\begin{array}{r}\text { Unstan } \\
\text { Coef }\end{array}$ & $\begin{array}{r}\mathrm{Co} \\
\text { ardizec } \\
\text { cients }\end{array}$ & $\begin{array}{l}\text { efficients }{ }^{\mathrm{a}} \\
\text { Standardized } \\
\text { Coefficients }\end{array}$ & \multirow[t]{2}{*}{ 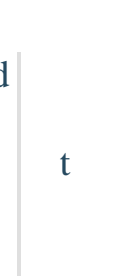 } & \multirow{2}{*}{ Sig. } & \multicolumn{2}{|c|}{$\begin{array}{l}\text { Collinearity } \\
\text { Statistics }\end{array}$} \\
\hline & B & $\begin{array}{l}\text { Std. } \\
\text { Error }\end{array}$ & Beta & & & Tolerance & VIF \\
\hline 1 (Constant) & 5,656 & 921 & & 6,144 &, 000 & & \\
\hline Arus Kas Operasi &,- 094 & 147 &,- 384 &,- 638 &, 528 & ,067 & 1,824 \\
\hline Arus Kas Investasi &,- 178 & , 120 &,- 860 & $-1,481$ & ,147 & ,072 & 1,812 \\
\hline Arus $\quad$ Kas & s, 317 & , 144 & 1,412 & 2,205 &, 034 & 059 & 1,811 \\
\hline
\end{tabular}

Berdasarkan tabel 6 dapat dibuat persamaan regresi linier berganda sebagai berikut :

$$
\begin{aligned}
& \text { "Y= 5,656 C }-0,094 \\
& \mathrm{X}_{1}-0,178 \text { X2+0,317 } \\
& \text { X3" }
\end{aligned}
$$

Melalui persamaan regresi linear berganda tersebut,maka dapat diuraikan penjelasan sebagai berikut:

1. Nilai konstanta sebesa 5,656 memberikan arti bahwa jika nilai arus kas operasi, arus kas investasi,dan arus kas pendanaan adalah 0 (nol),maka nilai harga saham adalah sebesar 5,656 ".

2. Nilai koefisien arus kas operasi sebesar 0,094 menunjukkan bahwa jika nilai arus kas operasi turun sebesar 1(satu), maka nilai harga saham juga akan turun sebesar $-0,094$.
Nilai koefisien yang negatif menunjukkan bahwa variabel ini memiliki hubungan negatif terhadap harga saham".

3. Nilai koefisien arus kas investasi sebesar 0,178 menunjukkan bahwa jika nilai arus kas investasi turun sebesar 1 (satu), maka nilai harga saham juga akan turun sebesar $-0,178$. Nilai koefisien yang negatif menunjukkan bahwa variabel ini memiliki hubungan negatif terhadap harga saham".

4. Nilai koefisien arus kas pendanaan sebesar 0,317 menunjukkan bahwa jika nilai arus kas pendanaan naik sebesar1(satu), maka nilai harga saham juga akan naik sebesar 0,317 . Nilai koefisien yang positif menunjukkan bahwa variabel ini memiliki hubungan positif terhadap harga saham".

\subsection{HasilUji Hipotesis}

\subsubsection{Hasil uji signifikansi parsial (uji-t)}

Tabel 7. Hasil UjiSignifikansiParsial

\begin{tabular}{|c|c|c|c|c|c|}
\hline Model & B & Std.Error & & $T$ & $\mathrm{Sig}$ \\
\hline 1 (Constant) & 5,656 & ,921 & & 6,144 & ,000 \\
\hline Arus Kas Operasi &,- 094 & ,147 &,- 384 &,- 638 & ,528 \\
\hline Arus Kas Investasi &,- 178 & 120 &,- 860 & $-1,481$ & 147 \\
\hline Arus $\quad$ Kas & .317 & 144 & 1,412 & 2,205 &, 034 \\
\hline
\end{tabular}

$$
\text { Coefficients }^{\mathrm{a}}
$$

UnstandardizedCoefficien StandardizedCoefficient

Berdasarkan Tabel 6 dapat dilihat bahwa variabel arus kas operasi memiliki nilai thitung sebesar $-0,638<$ tabel 1,689 dengan tingkat signifikansi sebesar $0,52>0,05$ yang artinya variabel arus kas operasi dalam penelitian ini 
tidak berpengaruh terhadap harga saham. Variabel arus kas investas memiliki nilai thitung sebesar-1,481<ttabel 1,689 dengan tingkat signifikansi sebesar $0,14>0,05$ yang artinya variabel arus kas investasi dalam penelitian ini tidak berpengaruh terhadap harga
saham.Variabel arus kas pendanaan memiliki nilai thitung sebesar 2,205 > ttabel 1,689 dengan tingkat signifikansi sebesar $0,03<0,05$ yanga rtinya variabel arus kas pendanaan dalam penelitian berpengaruh terhadap harga saham".

\subsubsection{Hasil uji signifikansi simultan (uji-F)}

Tabel 8. HasilUjiSignifikansiSimultan

\begin{tabular}{lllll|c|c|c} 
& \multicolumn{2}{c}{ ANOVA $^{\mathrm{a}}$} \\
Model & \multicolumn{2}{c}{ Sum of } & Df & Mean Square & F & Sig. \\
\hline \multirow{2}{*}{1} & Regression & 10,856 & 3 & 3,619 & 2,003 & $131 \mathrm{~b}$ \\
\cline { 2 - 8 } & Residual & 63,223 & 35 & 1,806 & & \\
\cline { 2 - 8 } & Total & 74,079 & 38 & & & \\
\hline
\end{tabular}

a. Dependent Variable:Harga Saham

b. Predictors:(Constant),ArusKas Pendanaan,Arus Kas Investasi,Arus Kas Operasi

Sumber:DataDiolahdengan SPSS (2021)

Berdasarkan Tabel dapat dilihat bahwa nilai Fhitung sebesar 2,00< Ftabel 2,64 dengan tingkat signifikansi sebesar $0,13>0,05$ yang artinya dalam penelitian ini variabel arus kas operasi, arus kas investasi,dan arus kas pendanaan tidak berpengaruh terhadap harga saham".

\subsubsection{Hasil koefisien determinasi $\left(\mathbf{R}^{\mathbf{2}}\right)$}

Tabel 9. HasilKoefisienDeterminasi

\begin{tabular}{|c|c|c|c|c|c|}
\hline \multicolumn{6}{|c|}{ Model Summary ${ }^{b}$} \\
\hline Model & $\mathrm{R}$ & R Square & $\begin{array}{c}\text { Adjusted } \\
\text { Square }\end{array}$ & $\begin{array}{c}\mathrm{R} \text { Std.Error ofthe } \\
\text { Estimate }\end{array}$ & Durbin-Watson \\
\hline 1 &, $383^{\mathrm{a}}$ & 147 &, 173 & 1,34402 & ,595 \\
\hline
\end{tabular}

Berdasarkan Tabel dapat dilihat bahwa nilai adjustedRSquare sebesar 0,173 yang artinya dalam penelitian ini variabel arus kas operasi,arus kas investasi, dan arus kas pendanaan memiliki kontribusi terhadap harga saham sebesar $17,3 \%$ sedangkan selebihnya sebesar $82,7 \%$ dipengaruhi oleh variabel lain diluar penelitian ini.

\section{Kesimpulan}

Berdasarkan hasil penelitian ini maka dapat diuraikan kesimpulan sebagai berikut:

1. Arus Kas Operasi tidak berpengaruh terhadap harga saham perusahaan manufaktur sub sektor makanan dan minuman yang terdaftar di BEI. Hal ini disimpulkan berdasarkan perolehan hasil uji signifikansi parsial (uji-t) yang diperoleh nilai $t_{\text {hitung }}$ sebesar $-1,481<t_{\text {tabel }} 1,689$ dengan tingkat signifikansi sebesar $0,14>$ 0,05 . Arus Kas Invetasi tidak berpengaruh terhadap harga saham perushaan manufaktur sub sektor makanan dan minuman yang terdaftar di BEI Hal ini disimpulkan berdasarkan perolehan hasil uji signifikansi parsial (uji-t) yang diperoleh nilai $\mathrm{t}_{\text {hitung }}$ sebesar $-1,481<\mathrm{t}_{\text {tabel }} 1,689$ dengan tingkat signifikansi sebesar $0,14>0,05$. Hasil penelitianinijuga

sejalandenganpenelitianyang dilakukanoleh Muchran dan Tahib (2020) yang menyatakanbahwaarus kas investasitidakberpengaruhterhadaphargasaha m. Berbeda dengan penelitian yang dilakukan oleh Debbie Christine (2016) yang menyatakan bahwa Arus Kas Operasi berpengaruh Positif terhadap harga saham".

2. Arus Kas Pendanaan berpengerauh positif siginifikan terhadap harga saham perusahaan manufaktur sub sektor makanan dan minuman yang terdaftar di BEI. Hal ini disimpulkan berdasarkan perolehan hasil uji 
signifikansi parsial (uji-t) yang diperoleh nilai $t_{\text {hitung }}$ sebesar 2,205 $>t_{\text {tabel }} 1,689$ dengan tingkat signifikansi sebesar $0,03<0,05$. Hasil penelitianinijuga sejalandenganpenelitianyangdilakukanoleh Muchran dan Thaib (2020) yang menyatakanbahwa arus kas pendanaanberpengaruh terhadapharga saham. Berbeda dengan penelitian yang dilakukan oleh Saartje Dompas Laoh (2014) yang menyatakan bahwa Arus kas Pendanaan tidak berpengaruh signifikan terhadap harga saham"

3. Arus kas Operasi, Arus Kas Investasi, dan Arus Kas Pendanaan tidak berpengaruh terhadap harga saham perusahaan manufaktur sub sektor makanan dan minuman yang tedaftar di BEI. Hal ini disimpulkan berdasarkan perolehan hasil uji signifikansi simultan (uji-F) yang diperoleh nilai $F_{\text {hitung }}$ sebesar 2,00 $<\mathrm{F}_{\text {tabel }} 2,64$ dengan tingkat signifikansi sebesar $0,13>0,05$. hasil penelitian ini juga sejalan dengan penelitian yang dilakukan oleh Muchran dan Thaib (2020) yang menyatakan bahwa arus kas operasi, arus kas investasi, dan arus kas pendanaan berpengaruh terhadap harga saham".

\section{DAFTAR PUSTAKA}

Anggarsari, F. (2017). Manfaat Laporan Keuangan Yang Perlu Anda Ketahui. https://zahiraccounting.com/id/blog/manfaat -laporan-keuangan-yang-perlu-anda-ketahui/

Arrestia, R. (2018). Rasio Keuangan. https://rizkyarrestia.blogspot.com/2018/12/

Azka, A. (n.d.). saham. 6. https://www.academia.edu/12201597/Saham

Boby. (2020). Jenis-Jenis Saham dan Penjelasannya [Plus Perbedaannya]. https://lifepal.co.id/media/jenis-saham-dipasaran-untuk-investor-pemula/
Christine, D. (2016). Pengaruh Komponen Arus Kas Dan Laba Bersih terhadap Harga Saham (Studi Kasus pada Perusahaan Manufaktur Sektor Industri Barang Konsumsi yang terdaftar di Bursa Efek Indonesia Periode 2010-2014). Jurnal Keuangan Dan Bisnis, $5,1-12$.

Clipsmaida. (2013). Pasar Modal. https://clipsmaida.blogspot.com/2013/06/pas ar-modal.html

Communication, B. U. F. of E. \&. (2017). PSAK 2 (Penyesuaian 2014): Laporan Arus Kas. $30 \quad$ Aug. https://accounting.binus.ac.id/2017/08/30/ps ak-2-penyesuaian-2014-laporan-arus-kas/

Conference, I. A., Education, G., International, I., Academic, A., Conference, C., Business, T., \& Science, M. (n.d.). Proceedings of IAC in Vienna 2020.

Connelly, B. L., Certo, S. T., Ireland, R. D., \& Reutzel, C. R. (2011). Signaling theory: A review and assessment. Journal of Management, 37(1), 39-67. https://doi.org/10.1177/0149206310388419

Donni. (2017). Pengertian Variabel Bebas dan Terikat. https://satujam.com/variabel-bebasdan-terikat/\#: :text=Variabel terikat ialah faktor-faktor yang diamati dan diukur,variabel\%2C misalkan variabel waktu untuk bekerja \%28A\%29

Ekonomi, G. (2021). Jenis-jenis Saham. https://sarjanaekonomi.co.id/saham/

Fernazi, F. (2015). penyusuan-arus-kas @ www.kompasiana.com. https://www.kompasiana.com/trawdawr/55a 3befd4b7a61e20c63f383/penyusuan-aruskas 